\title{
ANALISIS PENGADAAN JASA INFLUENCER PADA SATUAN KERJA PEMERINTAH: STUDI KRITIS
}

\author{
Jamila Lestyowati ${ }^{1}$, Mandar Trisno Hadisaputra ${ }^{2}$ \\ ${ }^{1}$ Balai Diklat Keuangan Yogyakarta, ${ }^{2}$ Balai Diklat Keuangan Makasar
}

\begin{abstract}
Researches on the procurement of goods and services were carried out in any aspects, such as management, economics, law, finance and others. Many researches on procurement were conducted on various types of goods and services. However, it was a few researches discussed influencer procurement. Influencers are individuals with ability and skills to influence other parties due to their existing competencies. Many private companies hire influencers to promote their products or services. If it is seen from government side, there are many influencers used to disseminate policies. Influencers hiring requires procurement of goods and services. This study aims to evaluate influencer procurement in government work units. The research method was juridical empirical using primary and secondary data. Primary data came from interviews which were conducted with informants regarding the theme of influencer procurement to obtain field conditions. Secondary data came from legal materials in the form of statutory regulations and literature searches, and they were research results, news, and other secondary sources. The results showed that influencers were hired because of their wider reach with a large number of followers. The procurement of influencers was included in the category of procurement of goods which was specific to goods / other services / consulting services which were exempted, they were in the procurement of goods and services whose implementation was in established business practices.
\end{abstract}

\begin{abstract}
Abstrak
Penelitian mengenai pengadaan barang dan jasa dilakukan pada banyak aspek, misalnya manajemen, ekonomi, hukum, keuangan dan sebagainya. Penelitian tentang pengadaan juga banyak dilakukan pada beragam jenis barang dan jasa. Namun sangat sedikit yang membahas pengadaan influencer. Influencer merupakan individu dengan kemampuan dan keterampilan untuk memengaruhi pihak lain disebabkan kompetensi yang ada padanya. Selama ini influencer banyak dimanfaatkan oleh perusahaan swasta untuk memasarkan produk atau jasanya. Dari sisi pemerintah sendiri, mulai banyak penggunaan influencer untuk menyebarluaskan kebijakan. Penggunaan influencer memerlukan kegiatan pengadaan barang dan jasa. Penelitian bertujuan untuk mengevaluasi pengadaan influencer pada satuan kerja pemerintah. Metode penelitian adalah yuridis empiris menggunakan data primer dan sekunder. Data primer berasal dari wawancara yang dilakukan kepada informan terkait tema pengadaan influencer untuk mendapatkan kondisi lapangan. Data sekunder berasal dari bahan hukum berupa peraturan perundang-undangan dan penelusuran kepustakaan yaitu hasil penelitian, berita maupun sumber sekunder lainnya. Hasil penelitian menunjukkan bahwa influencer digunakan karena jangkauannya yang lebih luas dengan jumlah pengikut yang banyak.
\end{abstract}


Pengadaan influencer masuk pada kategori pengadaan barang bersifat khusus terhadap barang/jasa lainnya/ jasa konsultansi yang dikecualikan yaitu pada pengadaan barang dan jasa yang pelaksanaannya berada pada praktik bisnis yang mapan.

Keywords: influencer, media sosial, pengadaan barang dan jasa, pengadaan yang dikecualikan

JEL Clasification: H5, K2. 


\section{PENDAHULUAN}

\section{Latar Belakang}

Salah satu tahap pada siklus anggaran adalah tahap pelaksanaan anggaran. Tahap ini merupakan bagian penting karena terdapat pelaksanaan kegiatan pemerintah dan pembayarannya. Salah satu kegiatan yang ada di tahap pelaksanaan anggaran adalah Pengadaan Barang dan Jasa (PBJ). Kegiatan PBJ menyerap sebagian besar dana Anggaran Pendapatan dan Belanja Negara (APBN). Data Kemenkeu menyebutkan anggaran PBJ pada APBN 2018 sebesar 537 triliun rupiah, lebih tinggi dari anggaran PBJ 2017 yaitu 525 triliun rupiah dan 2016 sebesar 429 triliun rupiah (Kemenkeu, 2018). Kecenderungan peningkatan tajam selama lima tahun terakhir dilihat dari aspek kompleksitas barang/jasa yang diadakan maupun dari sisi kenaikan besaran anggaran pada belanja pengadaan barang dan jasa.

PBJ sangat berperan dalam pembangunan nasional yang direpresentasikan dengan PBJ pada satuan kerja. Pelayanan pemerintah kepada stakeholder-nya memerlukan kegiatan PBJ. Visi dan misi pemerintah harus direalisasikan melalui proses PBJ. Barang dan jasa yang dibutuhkan stakeholder dipenuhi dengan proses PBJ. Betham et al. (2019) menyebutkan bahwa dalam pengelolaan pemerintahan, penunaian kebutuhan akan barang dan jasa menjadi sisi penting yang menyatu dan tidak dapat dipisahkan. Di sisi lain, tidak semua kegiatan pemerintah pada proses PBJ langsung dimanfaatkan oleh pengguna.
Tantangan yang dihadapi pada era teknologi komunikasi dan informasi adalah memastikan proses PBJ berjalan efektif, efisien, transparan, terbuka, akuntabel, bersaing, dan tidak diskriminatif. Penggunaan internet di era industri 4.0 tidak dapat dihindarkan. Hampir semua bidang telah memanfaatkan penggunaan teknologi komunikasi dan informasi ini. Pada bidang PBJ, pemanfaatan teknologi dengan memaksimalkan penggunaan e-catalog dan e-tender.

Keberadaan internet membawa hal baru pada perkembangan dunia digital. Munculnya sosial media yang hidup di ranah publik seperti Twitter, Facebook, dan Instagram pada akhirnya menimbulkan tren baru kepada banyak aspek kehidupan. Salah satunya adalah bidang digital marketing. Selama ini konsep pemasaran konvensional digunakan oleh lembaga baik swasta maupun pemerintah. Tren media sosial ini memunculkan para influencer yang kemudian digunakan untuk memasarkan produk barang/jasa (Anjani, 2020).

Di sisi lain, banyak kebijakan pemerintah yang harus disosialisasikan kepada masyarakat, terutama pada masa krisis. Untuk melaksanakan kegiatan tersebut, pemerintah memerlukan strategi yang tepat karena kondisi masyarakat yang berbeda. Situasi krisis dapat melahirkan kekacauan informasi publik yang bisa menyebabkan hilangnya kepercayaan publik. Kredibilitas pemerintah diragukan dan melahirkan kebingungan di tengah masyarakat. Hal ini akan menambah kerentanan masyarakat akibat krisis yang berlangsung. Bahkan lebih jauh, bisa memberi peluang munculnya infodemic 
yang bisa berdampak lebih buruk dibandingkan pandemi itu sendiri (Wahyuni \& Ambardi, 2020). Menurut Kantor Staf Presiden, komunikasi merupakan bagian terpenting pada situasi dimana Indonesia menghadapi gangguan dari pandemi. Berdasarkan protokol komunikasi publik untuk penanganan Covid-19 yang diterbitkan oleh Kantor Staf Presiden, trust/ kepercayaan dari masyarakat harus diupayakan ada dan selalu dijaga supaya tidak muncul ketegangan dan panik di masyarakat sehingga penanganan pandemi dapat berjalan lancar (KSP, 2020).

Di sisi lain untuk menentukan dan mengadakan pekerjaan sosialisasi kebijakan melalui influencer harus melalui proses pengadaan barang dan jasa. Berdasarkan data ICW tentang aktivitas digital pemerintah selama tahun 2014 - 2018 terdapat penggunaan 1,29 triliun rupiah untuk aktivitas digital pemerintah (Gambar 1).

Beberapa contoh paket pekerjaan pengadaan influencer, pada LPSE Kemenparekraf didapatkan data paket pengadaan influencer tahun 2020 dengan nama paket yaitu paket publikasi melalui influencer Paket I, II, III dan IV yang setiap paket bernilai 1,5 miliar rupiah sampai 3,3 miliar rupiah (Kementerian Pariwisata dan Ekonomi Kreatif, 2020). Dari penelusuran penulis pada aplikasi Simpel Kemendikbud, didapatkan contoh pengadaan influencer pada Kemendikbud (Tabel 1).

Pengadaan influencer baik di Kemendikbud maupun di Kemenparekraf tersebut menggunakan jenis paket pekerjaan jasa lainnya. Nilai yang berbeda-beda untuk setiap paket pengadaan dilaksanakan dengan metode pemilihan penyedia berupa lelang umum, lelang sederhana, tender dan pengadaan langsung.

Muncul pro kontra di masyarakat mengenai penggunaan influencer oleh pemerintah. ICW menyebut pemerintah tidak percaya diri dengan programprogramnya hingga memerlukan influencer untuk melakukan sosialisasi (Indonesian Corruption Watch, 2020). Pakar kebijakan publik dari UI menyebutkan terdapat ketidakefisienan dalam penggunaan influencer untuk sosialisasi program atau kebijakan pemerintah selama ini (BBC, 2020). Namun menurut Kementerian Komunikasi dan Informatika (2018),

Gambar 1. Anggaran Belanja Pemerintah Untuk Aktivitas Digital Berdasarkan Kata Kunci

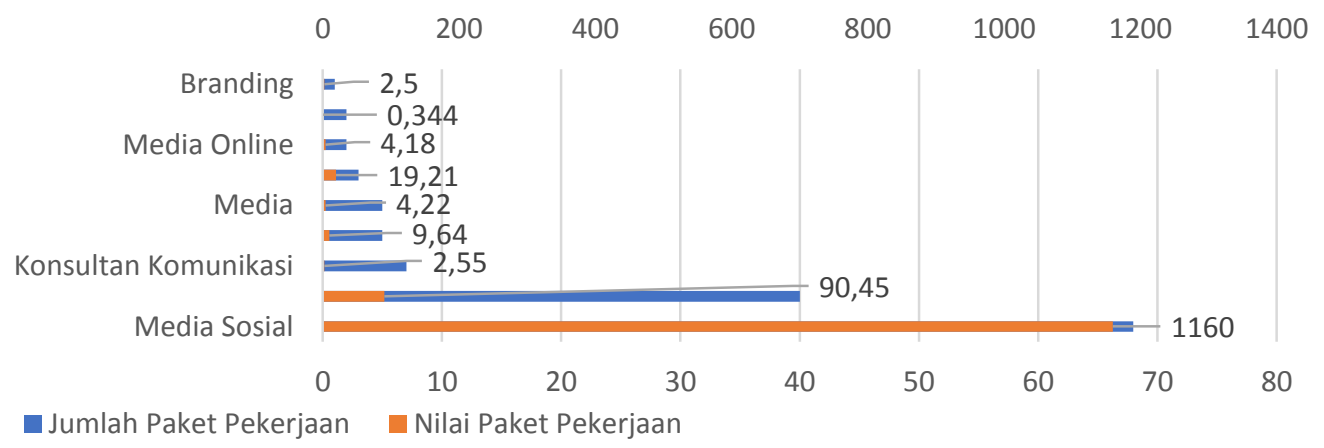

Sumber: ICW. 2020 
kebijakan menggunakan influencer

pengadaan langsung. Di lapangan

dilakukan

terjadi perbedaan proses dan perlakuan

Tabel 1. Contoh Pengadaan Influencer pada Kementerian Pendidikan dan Kebudayaan

\begin{tabular}{|c|c|c|c|c|}
\hline No & Paket Pekerjaan & Satker & Penyedia & Nilai Pengadaan \\
\hline 1 & $\begin{array}{l}\text { Sosialiasi V Factor melalui Key } \\
\text { Opinion Leader dan Influencer }\end{array}$ & $\begin{array}{l}\text { Sekditjen } \\
\text { Pendikan Vokasi }\end{array}$ & $\begin{array}{l}\text { CV Sukma Ade } \\
\text { Lamin }\end{array}$ & Rp. 195. 360.000 \\
\hline 2 & $\begin{array}{l}\text { Belanja Jasa Lainnya } \\
\text { Optimalisasi Publikasi PKN } \\
\text { Melalui Akun Micro Influencer } \\
\text { dalam rangka Publikasi Ditjen } \\
\end{array}$ & $\begin{array}{l}\text { Sekditjen } \\
\text { Kebudayaan }\end{array}$ & Jari Karya Mandiri & Rp 196.350 .000 \\
\hline 3 & $\begin{array}{l}\text { Pekerjaan Belanja Jasa Lainnya } \\
\text { Micro Influencer dalam Rangka } \\
\text { Indonesiana }\end{array}$ & $\begin{array}{l}\text { Sekditjen } \\
\text { Kebudayaan }\end{array}$ & Kreatif Media Unit & Rp. 192.000 .000 \\
\hline 4 & $\begin{array}{l}\text { Digital Influencer Kemah } \\
\text { Budaya Kaum Muda }\end{array}$ & $\begin{array}{l}\text { Sekditjen } \\
\text { Kebudayaan }\end{array}$ & Kreatif Media Unit & Rp. 175.000 .000 \\
\hline \multirow[t]{9}{*}{5} & \multicolumn{4}{|c|}{ Pengadaan Penayangan Sosialisasi PPDB melalui influencer media sosial artis } \\
\hline & $\begin{array}{l}\text { Gritte Agatha dan Ayushita } \\
\text { W.N. }\end{array}$ & $\begin{array}{l}\text { Sekretariat Ditjen } \\
\text { Dikdasmen (2019) }\end{array}$ & Zaskiya Ebertha & Rp. 114.400 .000 \\
\hline & Brisia Jodie dan Ghea Indrawan & $\begin{array}{l}\text { Sekretariat Ditjen } \\
\text { Dikdasmen (2019) }\end{array}$ & $\begin{array}{l}\text { PT Kurniawan Jaya } \\
\text { Pratama }\end{array}$ & Rp. 114.400 .000 \\
\hline & $\begin{array}{l}\text { Ahmad Jalaluddin Rumi dan Ali } \\
\text { Syakieb }\end{array}$ & $\begin{array}{l}\text { Sekretariat Ditjen } \\
\text { Dikdasmen (2019) }\end{array}$ & $\begin{array}{l}\text { PT Parama Cakra } \\
\text { Buana }\end{array}$ & Rp. 114.400 .000 \\
\hline & $\begin{array}{l}\text { Arif Muhammad dan Bastian } \\
\text { Steel }\end{array}$ & $\begin{array}{l}\text { Sekretariat Ditjen } \\
\text { Dikdasmen (2019) }\end{array}$ & $\begin{array}{l}\text { CV Ramsi Sinar } \\
\text { Sejahtera }\end{array}$ & Rp. 114.400 .000 \\
\hline & Salsabila Adriani & $\begin{array}{l}\text { Sekretariat Ditjen } \\
\text { Dikdasmen (2019) }\end{array}$ & $\begin{array}{l}\text { PT Raika Rizki } \\
\text { Haditama }\end{array}$ & Rp. 124.300 .000 \\
\hline & Yasmine Leeds Wildblood & $\begin{array}{l}\text { Sekretariat Ditjen } \\
\text { Dikdasmen (2019) }\end{array}$ & $\begin{array}{l}\text { PT Kimberly Nauli } \\
\text { Berkarya }\end{array}$ & Rp. 120.450 .000 \\
\hline & Zaskia Mecca dan Tasya K & $\begin{array}{l}\text { Sekretariat Ditjen } \\
\text { Dikdasmen (2019) }\end{array}$ & $\begin{array}{l}\text { Dwi Permana } \\
\text { Sejahtera }\end{array}$ & Rp. 129.800 .000 \\
\hline & Atta Halilintar dan Citra Kirana & $\begin{array}{l}\text { Sekretariat Ditjen } \\
\text { Dikdasmen (2019) }\end{array}$ & CV Imadha Karya & Rp. 136.950 .000 \\
\hline
\end{tabular}

Sumber: LPSE Kemendikbud, 2020

agar dapat menjangkau masyarakat yang lebih luas.

Pengadaan influencer menjadi tren di kalangan satker. Mekanisme pengadaan influencer mengikuti Perpres 16 tahun 2018 mengenai Pengadaan Barang dan Jasa Pemerintah dan Perpres perubahannya yaitu Perpres 12 tahun 2021 dan aturan turunannya. Dengan nilai tertentu, beberapa satker melaksanaan pengadaan influencer melalui untuk pengadaan influencer baik dari sisi penganggaran, mekanisme pemilihan, dokumen dan pekerjaan teknisnya.

Paper ini menyoroti kegiatan pengadaan influencer karena terdapat perbedaan pemahaman mengenai mekanisme pengadaannya. Penulis membagikan studi kritis atas pengadaan influencer untuk sumbangan pemikiran karena 
fenomena yang makin marak di satuan kerja pemerintah.

Rumusan masalah yang dibangun pada artikel ini adalah sebagai berikut:

a. Apakah jenis pengadaan yang tepat untuk pengadaan influencer dari jenis pengadaan barang dan jasa?

b. Bagaimana mekanisme pengadaan influencer?

Adapun tujuan penelitian artikel ini berdasarkan pada rumusan masalah, yaitu:

a. Mengidentifikasi jenis pengadaan influencer pada pengadaan barang dan jasa.

b. Mendeskripsikan mekanisme pengadaan influencer pada satuan kerja pemerintah.

\section{TINJAUAN LITERATUR}

\section{Gambaran Umum PBJ Pemerintah}

Pengadaan adalah salah satu fungsi pokok manajemen, baik itu pada sektor pemerintah maupun pada sektor swasta. Pengadaan memegang peranan penting pada semua lini organisasi dan memiliki pengaruh terhadap lingkungan, sosial dan ekonomi di seluruh siklus kehidupan dan meminimalisir dampak negatif. Pengertian pengadaan barang/jasa yaitu suatu aktivitas yang dilakukan untuk mendapatkan barang atau jasa dengan cara yang efisien, transparan dan efektif sesuai dengan keinginan dan keperluan penggunanya (Yukins \& Schooner, 2007). Marbun (2010) menyatakan bahwa ketika melaksanakan kegiatan pengadaan barang dan jasa, pengelola harus berpedoman pada alur pikir yang masuk logika dan sistematis melalui beragam cara untuk memperoleh barang dan jasa sesuai keinginan dengan mengikuti aturan dan prinsip yang berlaku, dengan berpedoman pada metode dan proses pengadaan yang standar. Sedangkan berdasarkan Perpres 16 tahun 2018 dan perubahannya pada pasal 1 ayat 1, PBJ yaitu

$\begin{array}{rr}\text { "Kegiatan } & \text { Pengadaan } \\ \text { Barang/Jasa } & \text { oleh }\end{array}$

Kementerian/Lembaga/Perangkat

Daerah yang dibiayai oleh APBN/APBD yang prosesnya sejak identifikasi kebutuhan, sampai dengan serah terima hasil pekerjaan".

Pelaku PBJ melaksanakan kegiatan pengadaan ini terdiri atas beberapa pihak yaitu PA, KPA, PPK, Kelompok Kerja Pemilihan, Pejabat Pengadaan, Agen Pengadaan, dan Penyelenggara Swakelola. Setiap pelaku PBJ memiliki tugas dan kewenangan masing-masing. Pelaku PBJ berada pada setiap tahap PBJ mulai dari perencanaan/persiapan sampai dengan pelaporan/pertanggungjawaban.

Barang/jasa dibutuhkan oleh instansi pemerintah lainnya untuk menjalankan fungsi dan tusinya. Kebutuhan akan barang/jasa tersebut berasal dari hasil identifikasi apa saja yang diperlukan pada tahun sebelumnya. Identifikasi ini disesuaikan dengan spesifikasi yang telah ditetapkan. Ketika melakukan identifikasi apa saja keperluan akan barang/jasa ini, maka akan dihasilkan luaran berupa daftar kebutuhan barang/jasa pemerintah. Kebutuhan akan barang/jasa ini akan memerlukan aktivitas pengadaan barang/jasa. Melalui keberadaan barang dan jasa, selain sebagai bagian dari pemenuhan tugas dan tanggung jawab pemerintah 
dalam usaha melayani masyarakat, juga sebagai aktivitas pemerintah untuk melaksanakan kegiatan pemerintahan (Betham et al., 2019).

Berdasarkan pasal 3 ayat 3 Perpres 16 tahun 2018 dan perubahannya, terdapat dua cara untuk melaksanakan kegiatan pengadaan barang/jasa. Cara ini diputuskan saat perencanaan umum pengadaan, yakni dengan melalui penyedia dan swakelola. Pengadaan dengan cara swakelola berdasarkan pasal 1 ayat 23 Perpres 16 tahun 2018 dan perubahannya dilaksanakan oleh $\mathrm{K} / \mathrm{L} / \mathrm{D} / \mathrm{I}$ dengan cara merencanakan, mengerjakan dan/atau mengawasi sendiri pekerjaan, dimana K/L/D/I sebagai penanggung jawab anggaran yang pelaksanaannya bisa oleh satker bersangkutan, lembaga pemerintah lainnya, organisasi/ lembaga masyarakat dan/atau kelompok masyarakat.

Sedangkan berdasarkan pasal 17 ayat 1 Perpres 16/2018 dan perubahannya, pengadaan melalui penyedia bisa berupa orang perseorangan atau badan usaha dengan terpenuhinya syarat dan sanggup mewujudkan tersedianya kebutuhan barang/jasa, wajib memenuhi kualifikasi sesuai dengan barang/jasa yang diadakan. Kegiatan pengadaan tersebut harus memperhatikan dan berdasarkan pada faktor yaitu:

1. Para pihak dalam pengadaan barang/jasa;

2. Tata nilai pengadaan;

3. Keikutsertaan usaha kecil;

4. Penggunaan barang/jasa hasil pembuatan dalam negeri;

5. Pengadaan barang/jasa dengan pelelangan/seleksi internasional;

6. Pengadaan secara elektronik;
7. Pengadaan barang/jasa yang pendanaannya dengan pinjaman/ hibah luar negeri;

8. Aman dan ramah terhadap lingkungan;

9. Peran serta perusahaan asing dalam pengadaan barang/jasa.

Pada era perkembangan TIK dewasa ini, penggunaan pengadaaan secara elektronik dilakukan memakai Sistem Pengadaan Secara Elektronik (SPSE). Penerapan e-procurement telah mengoptimalkan transparansi, efektivitas, efisiensi, dan pertanggungjawaban pelaksanaan pengadaan barang dan jasa pemerintah (Haryati et al., 2010 ; Arsyad et al., 2016), proses administrasi lebih sederhana dan harga penawaran yang lebih baik (Mulyono, 2017). Menurut Nayabarani (2018) juga lebih menguntungkan bagi penyedia dan masyarakat umum yang ingin mengetahui mekanisme pengadaan barang. Selain itu, penerapan e-government dalam mendukung transparansi pemerintah dan diduga dapat mereduksi potensi terjadinya korupsi.

\section{Jenis-Jenis Pengadaan Barang dan Jasa Pemerintah}

Satuan kerja pemerintah harus menetapkan kebutuhan barang/jasa pada dokumen penetapan barang. Identifikasi kebutuhan ini menjadi urgen karena akan menentukan proses berikutnya. Jenis barang/jasa yang ditetapkan meliputi pengadaan barang, pekerjaan konstruksi, jasa konsultansi, dan jasa lainnya. Secara umum definsi setiap jenis barang/jasa ini dijelaskan di pasal 1 Perpres 16/2018 dan perubahannya ayat 29 s.d. 32. Setiap jenis barang/jasa ini memiliki definisi yang berbeda-beda. Barang yaitu 
setiap kategori benda baik bergerak maupun tidak bergerak, berwujud maupun tidak berwujud, yang dapat dipergunakan, diperdagangkan, dimanfaatkan atau digunakan oleh pengguna barang. Sedangkan pekerjaan konstruksi ialah keseluruhan atau sebagian kegiatan pengadaan yang meliputi pengoperasian, pembangunan, pembongkaran, pemeliharaan, dan pembangunan kembali suatu bangunan. Jasa konsultansi yang dimaksud adalah jasa layanan secara profesional yang memerlukan keahlian tertentu di beragam bidang keilmuan yang mengedepankan adanya olah pikir. Sedangkan yang termasuk jasa lainnya adalah jasa non-konsultansi atau jasa yang memerlukan metodologi tertentu/khusus, peralatan, dan/atau keterampilan dalam suatu mekanisme tata kelola yang diketahui secara luas di dunia usaha untuk melaksanakan suatu pekerjaan tertentu (Pemerintah RI, 2018). Selain itu PPK juga melaksanakan identifikasi pada barang/jasa yang akan diadakan melalui PBJ apakah termasuk dalam klasifikasi pengadaan khusus. Hal ini karena kriteria barang/jasa yang berbeda. Peraturan LKPP No 9 tahun 2018 menyebutkan bahwa pengadaan khusus adalah:

"Pengadaan barang/jasa dalam rangka penanganan keadaan darurat; pengadaan barang/jasa di luar negeri; pengadaan barang/jasa yang masuk dalam pengecualian; penelitian; atau tender/seleksi internasional dan dana pinjaman luar negeri atau hibah luar negeri" (LKPP, 2018b).

Berdasarkan Peraturan LKPP Nomor 12 tahun 2018, pengecualian atas pengadaan barang/jasa dikenakan pada pengadaan barang/jasa dengan aturan dikecualikan, baik pada bagian tertentu maupun semuanya dari ketentuan pengadaan barang/jasa pemerintah yang ditetapkan dengan Perpres 16 tahun 2018 dan perubahannya. Hal ini agar pengadaan barang/jasa yang mudah dengan pengelolaan yang jelas dan unsur value for money dapat diwujudkan melalui pelaksanaan pengadaan. Ruang lingkup pengadaan ini meliputi beberapa pengadaan yaitu

"Pengadaan barang/jasa yang dilaksanakan atas dasar tarif barang/jasa yang diumumkan secara publik kepada masyarakat, pengadaan barang/jasa pada BLU, pengadaan barang/jasa yang dilaksanakan sesuai dengan praktik bisnis dunia usaha yang sudah memiliki pola dan mapan, dan/atau pengadaan barang/jasa yang ditetapkan dengan ketentuan peraturan perundang-undangan lainnya" (LKPP, 2018a).

Implementasi pengadaan barang/jasa berdasarkan praktik bisnis yang sudah mapan merupakan pengadaan yang tata laksana transaksinya dalam praktik berlaku secara publik dan terbuka sesuai dengan keadaan pasar pada umumnya dan sudah mempunyai mekanisme bisnis tersendiri. Pengadaan ini meliputi:

a. Adanya ketetapan mengenai standar biaya untuk harga satuan barang/jasa oleh pemerintah pada implementasi transaksi dan jenis kegiatannya sudah berlangsung secara umum pada kompetisi usaha yang terbuka dan sehat;

b. Jumlah penawaran (excess demand) lebih kecil dibandingkan 
Tabel 2. Contoh PBJ Sesuai dengan Praktik Bisnis yang Telah Mapan

\begin{tabular}{|c|c|c|}
\hline No & Praktik Bisnis yang Sudah Mapan & Contoh \\
\hline 1 & $\begin{array}{l}\text { Praktik bisnis dengan adanya ketetapan mengenai } \\
\text { standar biaya untuk harga satuan oleh } \\
\text { pemerintah, implementasi atas kegiatan usaha } \\
\text { tersebut sudah berlaku umum dengan adanya } \\
\text { persaingan usaha yang terbuka, siapapun dapat } \\
\text { mengikuti dan sehat }\end{array}$ & $\begin{array}{l}\text { Jasa akomodasi pada hotel } \\
\text { Jasa tiket pada moda pengangkutan/ } \\
\text { transportasi } \\
\text { Berlangganan majalah/ koran }\end{array}$ \\
\hline 2 & $\begin{array}{l}\text { Jumlah penawaran (excess demand) lebih kecil } \\
\text { dibandingkan permintaan atas barang/jasa } \\
\text { dan/atau memiliki aspek pengelolaan pasar } \\
\text { terpisah sehingga dalam hal ini pihak pembeli } \\
\text { sebagai pihak yang memiliki kebutuhan yang } \\
\text { menyampaikan penawaran kepada penjual }\end{array}$ & $\begin{array}{l}\text { Partisipasi pada diklat/ seminar } \\
\text { Penelitian/jurnal/publikasi ilmiah/laporan riset } \\
\text { Kapal bekas } \\
\text { Pesawat bekas } \\
\text { Sewa gudang/gedung }\end{array}$ \\
\hline 3 & $\begin{array}{l}\text { Jenis jasa pada profesi tertentu dimana memiliki } \\
\text { layanan keahlian, kode etik, standar atas imbalan } \\
\text { jasa berupa remunerasi, honor, dan praktik } \\
\text { marketing dari perhimpunan profesi }\end{array}$ & $\begin{array}{l}\text { jasa penasihat hukum/ pengacara } \\
\text { Jasa arbiter } \\
\text { jasa PPAT/Notaris } \\
\text { jasa tenaga kesehatan } \\
\text { jasa penerjemah/interpreter } \\
\text { jasa auditor } \\
\text { jasa penilai }\end{array}$ \\
\hline 3 & $\begin{array}{l}\text { Barang/jasa sebagai bentuk karya seni dan budaya } \\
\text { dan/atau dari industri kreatif }\end{array}$ & $\begin{array}{l}\text { Sewa, pembuatan, pembelian: } \\
\text { Film/ iklan layanan masyarakat/ barang budaya } \\
\text { dan seni } \\
\text { jasa budaya dan pekerja seni }\end{array}$ \\
\hline
\end{tabular}

Sumber: Peraturan LKPP nomor 9 tahun 2018

permintaan atas barang/jasa dan/atau memiliki tata kelola market tersendiri sehingga dalam hal ini pihak pembeli sebagai pihak yang memiliki kebutuhan barang/jasa yang membuat penawaran kepada pihak penjual;

c. Jasa profesi tertentu yang sudah memiliki layanan keahlian, kode etik, standar remunerasi atau balas jasa berupa imbalan atau honorarium, dan praktik pemasaran yang telah diputuskan oleh perhimpunan profesinya; d. Barang/jasa sebagai karya seni dan budaya dan/atau barang/jasa dari industri kreatif.

Contoh PBJ sesuai dengan praktik bisnis yang telah mapan, namun tidak terbatas pada pengadaan berikut (Tabel 2).

Dalam menentukan kebutuhan barang/ jasa, pengelola pengadaan satuan kerja yaitu Kuasa Pengguna Anggaran (KPA) dan Pejabat Pembuat Komitmen (PPK) dituntut memiliki rencana strategis yang tepat. Baldus \& Hatton (2020) menyinggung bahwa sebagai pejabat publik, pengelola pengadaan menghadapi serangkaian 
faktor kelembagaan yang unik pada konteks pengadaan yang menarik, menantang, dan penting. Ketika menyusun kebutuhan rencana kebutuhan, pihak yang berwenang dihadapkan dengan beragam alternatif. Baldus \& Hatton (2020) menyinggung kembali bahwa pengelola pengadaan pemerintah menghadapi masalah struktural misalnya keterbatasan anggaran juga masalah efisiensi dan efektivitas pada berbagai opsi pengadaan. Sama seperti industri swasta, kendala sumber daya dihadapi pengelola pengadaan karena mereka mencari nilai terbaik bagi pemangku kepentingan mereka dalam arti sebagai pencapaian optimal manfaat barang dan jasa melalui biaya.

Salah satu faktor dalam menentukan kebutuhan barang dan jasa adalah pelaksanaan pemerintahan secara elektronik. Konsep penyelenggaraan pemerintahan tidak hanya dilakukan secara konvensional/tradisional. Caloghirou (2016) menyebutkan bahwa cara pelayanan publik yang diberikan pemerintah dan cara pemerintah berinteraksi dengan warga dan dunia usaha telah diubah melalui $e$ government.

Pemerintah dengan melihat pengadaan kompetitif antar penyedia mendorong kualitas pengadaan dan menurunkan biaya, sebagai prinsip dari peraturan pengadaan publik (Uenk \& Telgen, 2019). Walaupun demikian, penelitian Uenk \& Telgen (2019) menemukan sebagian kecil unit pemerintah menggunakan mekanisme pasar dalam pengadaan mereka. Beberapa studi menunjukkan bahwa dalam praktiknya, pengadaan jasa lebih menantang daripada pengadaan barang (Wynstra, 2018).

\section{Metode Pemilihan Penyedia}

Menurut Kamus Besar Bahasa Indonesia (KBBI) yang disebut metode ialah sebuah sistem pada cara kerja tertentu untuk memperlancar pelaksanaan kegiatan dalam rangka mendapatkan tujuan tertentu. Jadi definisi metode pemilihan adalah tata cara dengan melalui tahapan tertentu untuk melakukan pemilihan penyedia barang/jasa untuk mendapatkan penawaran yang sesuai dengan kebutuhan pengguna akhir barang/jasa. Sesuai Perpres 16 tahun 2018 dan perubahannya, metode pemilihan untuk pengadaan barang/jasa dibedakan ke dalam sifat pengadaan yang bersifat umum dan pengadaan khusus. Metode pemilihan pada pengadaan yang bersifat umum

Tabel 3. Metode Pemilihan Pengadaan Bersifat Umum

\begin{tabular}{|c|l|l|l|}
\hline No & Sifat Pengadaan & \multicolumn{1}{|c|}{ Jenis Pengadaan } & \multicolumn{1}{c|}{ Metode pemilihan } \\
\hline 1 & $\begin{array}{l}\text { Pengadaan } \\
\text { Umum }\end{array}$ & $\begin{array}{l}\text { Barang/PekerjaanKonstruksi/ } \\
\text { Jasa Lainnya }\end{array}$ & $\begin{array}{l}\text { Pengadaan Langsung, penunjukan } \\
\text { langsung, tender dan tender cepat, } e- \\
\text { purchasing }\end{array}$ \\
\cline { 3 - 4 } & Jasa Konsultansi & $\begin{array}{l}\text { Seleksi, pengadaan langsung, } \\
\text { penunjukan langsung. }\end{array}$ \\
\hline
\end{tabular}

Sumber: Perpres 16 tahun 2018 dan Perubahannya 
dibedakan menurut jenis pengadaan sebagaimana dijelaskan pada tabel 3.

Sistem pengadaan barang/jasa yang baik adalah sistem pengadaan dimana prinsip-prinsip tata pemerintahan yang baik (good governance) diterapkan, mendorong efisiensi dan efektivitas pengeluaran anggaran dalam penyelenggaaan tata pemerintahan yang baik (Yulianto, 2017). Pelaksanaan pemilihan penyedia melalui pengadaan langsung dilaksanakan oleh Pejabat Pengadaan (PP) untuk beberapa metode pemilihan. Pengadaan Langsung dipakai untuk barang/jasa lainnya dengan harga yang telah fix yang nilai pengadaannya maksimal 50 juta rupiah, diterapkan dengan langkah sebagai berikut:

1. PP melakukan pemesanan ke Penyedia;

2. Serah terima Barang/Jasa Lainnya dilaksanakan oleh penyedia dan PPK melaksanakan;

3. Penyedia menyerahkan bukti pembelian atau bukti pembayaran maupun kuitansi kepada PPK; dan/atau

4. PPK kemudian melaksanakan pembayaran.

PPK dalam melaksanakan pengadaan secara langsung dapat meminta bantuan kepada tim pendukung.

Pengadaan Langsung untuk Jasa Konsultansi yang memiliki nilai pengadaan paling banyak 100 juta rupiah, Barang/Jasa Lainnya dengan nilai pengadaan di atas 50 juta rupiah sampai dengan nilai maksimal 200 juta rupiah; dan Pekerjaan Konstruksi dengan nilai pengadaan paling banyak 200 juta rupiah dilaksanakan dengan tahapan sebagai berikut:
1. Pejabat pengadaan mencari data mengenai harga dan pekerjaan yang akan dilaksanakan, antara lain dilakukan melalui media digital/ secara elektronik maupun nondigital/ elektronik.

2. Jika informasi tersebut sudah ada, pejabat pengadaan membuat perbandingan antara harga dan kualitas barang/jasa minimal berasal dari dua sumber jenis data yang berbeda.

3. Calon Penyedia yang diyakini memiliki kemampuan dimintakan oleh pejabat pengadaan untuk mengirimkan penawaran baik dari aspek administrasi, harga, teknis, dan kualifikasi.

4. Spesifikasi teknis, gambar dan dokumen lain yang menunjukkan apa saja jenis pekerjaan yang diperlukan, dilampirkan oleh PP saat menyampaikan undangan tersebut.

5. Penyampaian penawaran administrasi, teknis, harga, dan kualifikasi oleh calon penyedia yang diundang dilaksanakan sesuai waktu yang ditentukan dalam undangan secara langsung.

6. PP membuka penawaran dari penyedia dan melakukan evaluasi secara administrasi, teknis dan kualifikasi. Evaluasi menggunakan sistem gugur. PP kemudian mengklarifikasi teknis dari pekerjaan dan melakukan negosiasi harga untuk memperoleh rekanan dengan harga yang dapat dipertanggungjawabkan dan wajar.

7. PP melakukan negosiasi harga didasarkan pada HPS/ informasi lain yang diperoleh.

8. Jika tahapan negosiasi harga ini belum mendapatkan persetujuan, 
maka pengadaan Langsung ini dikatakan gagal dan kemudian dilakukan pengadaan langsung ulang. Pengulangan ini dilakukan dengan mengundang vendor lain.

9. PP membuat Berita Acara Hasil Pengadaan Langsung yang berisi:
a) Nama rekanan beserta alamatnya;
b) Harga yang ditawarkan oleh penyedia yang sudah terkoreksi dan harga berdasarkan hasil kesepakatan;
c) Jika ada, elemen yang dilakukan evaluasi;
d) Jika ada, hasil negosiasi/kesepatakan harga;
e) Hal lainnya yang dirasa perlu; dan

Tabel 4. Metode Pemilihan Pengadaan Bersifat Khusus terhadap Barang/Jasa Lainnya/Jasa Konsultansi yang dikecualikan

\begin{tabular}{|c|c|c|c|}
\hline No. & $\begin{array}{l}\text { Kelompok PBJ yang } \\
\text { dikecualikan }\end{array}$ & $\begin{array}{l}\text { Sub Kelompok PBJ yang } \\
\text { dikecualikan }\end{array}$ & Metode Pemilihan \\
\hline 1 & PBJ pada BLU & - & $\begin{array}{l}\text { berdasarkan } \\
\text { pimpinan BLU }\end{array}$ \\
\hline 2 & $\begin{array}{l}\text { PBJ berdasarkan tarif } \mathrm{B} / \mathrm{J} \\
\text { yang diumumkan secara } \\
\text { luas }\end{array}$ & - & $\begin{array}{l}\text { sesuai mekanisme pasar yang } \\
\text { ditetapkan penyedia }\end{array}$ \\
\hline \multirow[t]{4}{*}{3} & \multirow[t]{4}{*}{$\begin{array}{l}\text { PBJ yang pelaksanaannya } \\
\text { berada pada praktik } \\
\text { bisnis yang mapan }\end{array}$} & $\begin{array}{l}\text { Adanya standar biaya untuk } \\
\text { harga satuan yang dibuat oleh } \\
\text { pemerintah; kegiatan usahanya } \\
\text { dilaksanakan secara umum } \\
\text { pada kompetisi usaha yang } \\
\text { sehat dan berlaku terbuka }\end{array}$ & $\begin{array}{l}\text { non kompetisi } \\
\text { kompetisi }\end{array}$ \\
\hline & & $\begin{array}{l}\text { Adanya mekanisme pasar } \\
\text { tersendiri dan excess demand } \\
\text { (pihak penjual yang menerima } \\
\text { penawaran dari pembeli) }\end{array}$ & $\begin{array}{l}\text { PP/Pokja Pemilihan mengikuti } \\
\text { lelang dan menyampaikan } \\
\text { penawaran kepada penyedia. } \\
\text { Metode lelang sesuai yang } \\
\text { ditetapkan (penyedia) }\end{array}$ \\
\hline & & $\begin{array}{l}\text { jasa profesi tertentu dengan } \\
\text { standar renumerasi dan kode } \\
\text { etik }\end{array}$ & $\begin{array}{l}\text { non kompetisi } \\
\text { kompetisi }\end{array}$ \\
\hline & & $\begin{array}{l}\text { barang/jasa sebagai karya seni } \\
\text { dan budaya dan/atau hasil } \\
\text { industri kreatif }\end{array}$ & $\begin{array}{l}\text { non kompetisi } \\
\text { kompetisi }\end{array}$ \\
\hline 4 & $\begin{array}{l}\text { PBJ yang diatur per-UU } \\
\text { lainnya }\end{array}$ & PBJ yang diatur per-UU lainnya & $\begin{array}{l}\text { Seperti diatur pada masing- } \\
\text { masing perundang-undangan }\end{array}$ \\
\hline
\end{tabular}

Sumber: Perlem Nomor 12 tahun 2018 
f) waktu dibuat Berita Acara yaitu tanggalnya.

10. PP kemudian menyampaikan hasil pengadaan langsung kepada PPK.

Negosiasi diperlukan agar unit kerja mendapatkan harga yang wajar dengan kualitas barang/jasa yang bagus. Hutagalung (2015) menyebutkan bahwa dalam jika pemilihan rekanan pada masa pra kontrak melalui mekanisme seleksi, pada metode penunjukan langsung dan pengadaan langsung dilakukan negosisasi mengenai harga dan kualitas teknis barang/jasa untuk mencapai kesepakatan antara pemerintah dan penyedia.

Jika berdasarkan pertimbangan $\mathrm{PP}$, pelaku usaha tersebut mempunyai kompetensi dalam melaksanakan pekerjaan, calon Penyedia tidak dikenakan kewajiban memberikan formulir isian kualifikasi.

Untuk pengadaan yang bersifat khusus dalam kelompok pengadaan barang/jasa yang dikecualikan, metode pada pemilihan penyedia dijelaskan sebagaimana tabel 4. Metode pemilihan penyedia untuk pengadaan yang dikecualikan pada kelompok pengadaan yang pelaksanaannya sesuai dengan praktik bisnis yang sudah mapan dilakukan dengan metode pemilihan kompetisi, nonkompetisi, dan lelang.

Pengadaan dilakukan melalui beberapa tahapan untuk jasa profesi tertentu yang tolak ukur pada imbalan jasa baik berupa honorarium atau remunerasi, memiliki praktik marketing, layanan jasa keahlian, dan kode etik perkumpulan profesinya.

Peraturan LKPP tentang Pedoman Perencanaan Pengadaan Barang/Jasa Pemerintah digunakan sebagai dasar untuk menetapkan tahapan perencanaan jasa profesi tertentu. Perkiraan atas biaya/Rencana Anggaran Biaya (RAB) disusun dengan mempertimbangkan patokan remunerasi yang ditetapkan oleh Asosiasi Jasa Profesi.

Adapun tahapan persiapan pengadaan dengan beberapa kegiatan. Dengan mempertimbangkan pagu anggaran dalam dokumen anggaran dan patokan remunerasi dari asosiasi profesi, PPK merancang perkiraan 4 anggaran/RAB. PPK kemudian merancang Kerangka Acuan Kerja (KAK) pekerjaan, dan menyusun rancangan kontrak. PPK menyampaikan dokumen berupa prediksi perhitungan biaya/anggaran, KAK Pekerjaan, dan rencana kontrak kepada PP/UKPBJ.

Sedangkan tahapan persiapan dan pelaksanaan pada pemilihan penyedia dilakukan melalui kompetisi dan nonkompetisi. Tahapan ini dilaksanakan oleh PP/Pokja Pemilihan dan Tim Teknis.

PP/Pokja Pemilihan dibantu tim teknis menyiapkan perhitungan harga pasar dari barang/jasa dan parameter teknis. Hal ini untuk mempermudah pelaksanaan pengadaan nantinya.

PBJ pada nilai pagu anggaran paling sedikit di atas 200 juta rupiah proses pemilihan penyedia dilaksanakan dengan cara kompetisi oleh Pokja Pemilihan. Sedangkan dalam hal portofolio atau hak eksklusif atas barang/jasa disamping karena faktor reputasi yang dimiliki jasa profesi yang dibutuhkan satuan kerja hanya bisa dimiliki oleh satu penyedia dengan nilai pagu anggaran minimal di atas 200 juta rupiah, maka pokja pemilihan melaksanakan pemilihan penyedia dengan cara non-kompetisi. Jika nilai 
pagu anggaran untuk pengadaan tersebut paling banyak 200 juta rupiah maka dilaksanakan oleh PP.

Persiapan dan pelaksanaan pemilihan melalui kompetisi dilakukan minimal melewati langkah yaitu:

1. Survei pasar dilaksanakan oleh tim teknis dan pokja pemilihan untuk melihat ada tidaknya jasa profesi seperti parameter yang ditetapkan;

2. Pengadaan atas jasa profesi diumumkan oleh Pokja Pemilihan dan dapat juga dilakukan dengan mengundang Peserta/ penyedia untuk mengirimkan proposal;

3. Evaluasi proposal berbasis kualitas dilakukan oleh Pokja Pemilihan dibantu Tim Teknis;

4. Jika diperlukan peserta dapat diundang Pokja Pemilihan untuk melakukan wawancara atau memberikan presentasi. Pokja Pemilihan dan Tim Teknis akan memberikan evaluasi dan memberi nilai atas proposal dan hasil presentasi/wawancara tersebut;

5. Penetapan yang terpilih didasarkan pada nilai tertinggi; dan

6. Melakukan negosiasi teknis dan harga oleh pokja pemilihan dengan penyedia terpilih.

Persiapan dan pemilihan penyedia dengan cara non-kompetisi dilakukan minimal dengan langkahlangkah yaitu (1) Identifikasi pelaku usaha yang dianggap mampu oleh Pokja Pemilihan/ pejabat pengadaan dan Tim Teknis; (2) Satu pelaku usaha yang diyakini memiliki kemampuan akan diundang untuk mengirimkan proposal oleh PP/Pokja Pemilihan; (3) Selain itu PP/Pokja Pemilihan juga dapat menyampaikan undangan kepada peserta untuk memberikan paparan/melakukan wawancara. (4)
Penilaian dilakukan oleh Tim Teknis atas proposal dan hasil wawancara tersebut; (5) Hasil penilaian proposal disampaikan oleh tim teknis kepada PP/Pokja Pemilihan; (6) PP/Pokja Pemilihan melakukan kesepakatan harga jika hasil penilaian proposal memenuhi kriteria teknis.

Berdasarkan bukti perjanjian baik berupa SPK/Surat Perjanjian, pelaksanaan tahap kontrak dilaksanakan baik oleh PP maupun PPK melalui tahap pembayaran kepada Penyedia.

\section{Mekanisme Perencanaan Pengadaan Influencer}

Kegiatan perencanaan kegiatan merupakan bagian dari tahap persiapan anggaran, yaitu perencanaan dan penganggaran. Satuan kerja melakukan identifikasi kebutuhan barang dan jasa berdasarkan program dan kegiatan pada rencana kerjanya. Proses perencanaan dan penganggaran, keduanya sering disatukan menjadi bagian dari sisi integral penyusunan rencana kegiatan dan kebutuhan anggaran. Arora \& Talwar (2020) menyebutkan bahwa proses penganggaran baik oleh individu maupun pemerintah merupakan tugas berat untuk melaksanakannya, sebuah istilah yang mengacu pada rencana pengeluaran yang diperlukan dalam jangka waktu tertentu.

Rencana Kerja K/L dan RKA-K/L disusun oleh Menteri/Pimpinan Lembaga untuk Kementerian/Lembaga yang dipimpinnya dalam rangka penyusunan APBN. Tiga materi pokok diatur pada proses penyusunan RKA$\mathrm{K} / \mathrm{L}$ yaitu pendekatan instrumen RKAKL, penyusunan anggaran, dan klasifikasi anggaran. 
Dalam penyusunan anggaran, Kementerian Negara/Lembaga (K/L) mengacu kepada Peraturan Menteri Keuangan Republik Indonesia Nomor 208/PMK.02/2019 Tentang Petunjuk Penyusunan dan Penelaahan Rencana Kerja Dan Anggaran Kementerian Negara/Lembaga Dan Pengesahan Daftar Isian Pelaksanaan Anggaran (Kemenkeu, 2015).

Satuan kerja mengidentifikasi kebutuhan influencer berdasarkan rencana kerjanya, misalnya untuk kegiatan publikasi, sosialisasi, atau diseminasi peraturan/kebijakan. Kegiatan ini dapat melekat pada fungsi kehumasan satuan kerja. Satker mengidentifikasi sasaran dari informasi yang akan disampaikan, misalnya kelompok praktisi, masyarakat awam, remaja, mahasiswa, murid sekolah dan lain-lain. Setelah kelompok sasaran teridentifikasi, satker membuat rincian kegiatan, jadwal pelaksanaan kegiatan, dan cara pengadaan. Setiap pengadaan influencer yang akan dilaksanakan sudah masuk ke dalam RKAKL-nya dan rincian biaya terdapat di POK. Pada tahap perencanaan ini sudah diketahui berapa harga/tarif dari influencer tersebut. Dokumen Kerangka Acuan Kerja (KAK) dan Rincian Anggaran Biaya (RAB) sudah disusun sedemikian rupa sehingga menjadi dokumen pendukung kegiatan pengadaan. Melalui dokumen penganggaran satker, anggaran negara dilaksanakan untuk tujuan value for money melalui efisiensi pendanaan. Nilai efisiensi dilaksanakan nantinya bukan hanya untuk perencanaan dan penganggaran, namun juga untuk pelaksanaannya. Arora \& Talwar (2020) menyebutkan bahwa dalam mengelola pendapatannya atau sumber dayanya pemerintah harus efisien sedemikian rupa sehingga dapat memaksimalkan pengeluaran negara untuk kebutuhan pokok dasar seperti kesehatan, pendidikan, dan kegiatan lain untuk mempertahankan pertumbuhan yang berkelanjutan.

\section{METODOLOGI PENELITIAN}

Penelitian pada paper ini merupakan penelitian yuridis empiris atau dikenal dengan istilah sosio legal yaitu penelitian hukum mengenai pemberlakuan atau implementasi ketentuan hukum normatif secara in action pada setiap peristiwa hukum tertentu yang terjadi dalam masyarakat. Penelitian ini berfokus pada bekerjanya hukum dalam masyarakat (Ishaq, 2017). Obyek kajian penelitian ini adalah implementasi aturan hukum yaitu Perpres 16/2018 dan perubahannya dan Peraturan LKPP Nomor 12 tahun 2018.

Penelitian yuridis empiris merupakan jenis penelitian lapangan atau penelitian terhadap data primer untuk melihat perilaku yang hidup di tengah-tengah masyarakat dan digabung dengan penelitian pada peraturan-peraturan hukum. Fungsinya adalah untuk mengevaluasi implementasi peraturan pengadaan influencer dan kerja dari institusi hukum berupa pengelola pengadaan.

Data/materi pokok dalam penelitian ini diperoleh secara langsung dari informan melalui penelitian lapangan. Sumber data berasal dari data primer yaitu hasil wawancara dengan informan dari Kanwil DJKN Jawa Timur yaitu pejabat pengadaan yang mempunyai pengadaan influencer di unit kerjanya. Sedangkan data 
sekunder berasal dari bahan hukum primer berupa peraturan perundangan yaitu Perpres pengadaan barang dan jasa dan peraturan LKPP, bahan hukum sekunder berupa paper pada jurnal dan buku. Literatur teknis tentang pengadaan influencer memberikan konsep dan hubungan yang telah teruji pada data nyata sekaligus merangsang kepekaan teoritik (Strauss \& Corbin, 2017).

Analisis data dilakukan secara kualitatif yakni menguraikan data secara berkualitas dan komprehensif dalam bentuk kalimat yang teratur, logis, tidak tumpang tindih dan efektif sehingga memudahkan pemahaman dan interpretasi data (Ishaq, 2017). Metode analisis isi (content analysis) digunakan sebagai metode analisis data yang berarti tema-tema, isu-isu, dan motif-motif yang terkandung di dalamnya dipisahkan, dihimpun dan diintepretasikan (Denzin \& Lincoln, 2009).

\section{Kerangka Pemikiran}

Gambar 2. Kerangka Pemikiran

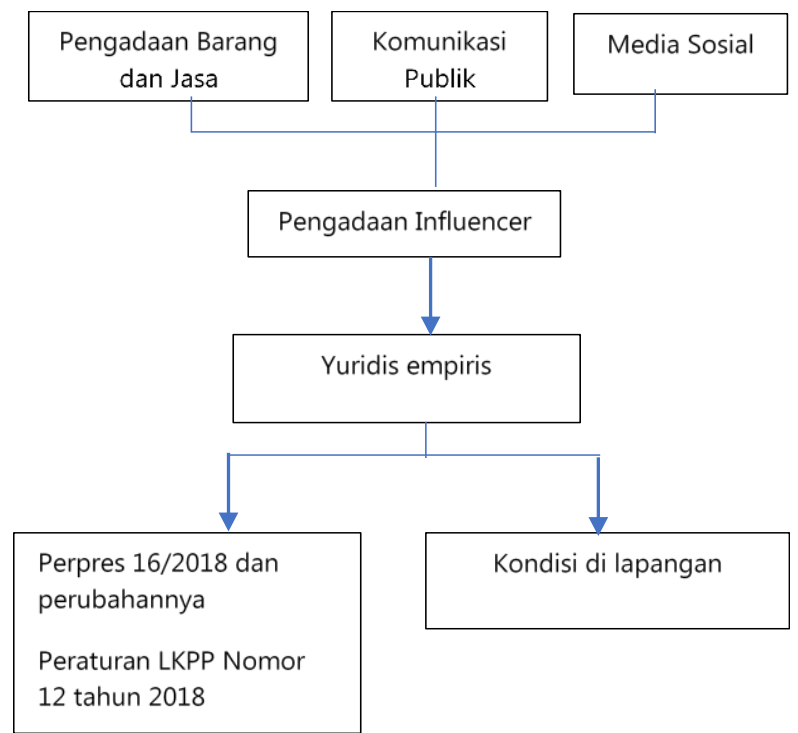

Sumber: Penulis

\section{HASIL PENELITIAN DAN PEMBAHASAN}

Perencanaan dan penganggaran influencer pada satuan kerja belum berjalan optimal. Pada satuan kerja Kanwil DJKN Jawa Timur pengadaan influencer baru direncanakan pada tahun berjalan pada saat akan dilaksanakan pengadaan. Identifikasi kebutuhan terjadi pada kondisi pandemi dan satuan kerja memerlukan peran influencer untuk menyampaikan kebijakan satker kepada masyarakat. Proses perencanaan dan penganggaran seharusnya sejalan dengan penyusunan RKAKL, namun dimungkinkan pada saat tahun anggaran berjalan. Hal ini jika terdapat kondisi yang menyebabkan terjadinya perubahan kegiatan yang mengakibatkan perubahan pada penganggarannya.

Instruksi Presiden Nomor 9 tahun 2015 tentang Pengelolaan Komunikasi Publik menginstruksikan kepada para Menteri, Kepala Lembaga Negara dan Kepala Daerah untuk mengambil langkah-langkah yang diperlukan sesuai tugas, fungsi dan kewenangan masing-masing dalam rangka mendukung pelaksanaan komunikasi publik, salah satunya dengan menyampaikan informasi melalui berbagai saluran komunikasi kepada masyarakat secara tepat, cepat, obyektif, berkualitas baik, berwawasan nasional dan mudah dimengerti terkait dengan kebijakan dan program pemerintah (Pemerintah RI, 2015). Menteri Kominfo, Johnny G Plate menjelaskan (Direktorat Jenderal Aplikasi Informatika, 2020):

"Komunikasi harus bisa ditingkatkan agar dapat menyentuh seluruh lapisan masyarakat. 
Penggunaan influencer ini salah satu upayanya."

Oleh karena itu influencer dari pihak eksternal dibutuhkan dengan melihat pertimbangan tertentu.

Proses perencanaan dilakukan secara terencana dan transparan. Perencanaan yang tidak transparan berimplikasi pada tidak terpantaunya besaran dan realisasi jumlah anggaran pengadaan barang dan jasa di Indonesia serta tidak terdeteksinya penyimpangan perencanaan PBJ secara dini seperti yang dinyatakan oleh Nayabarani (2018). Kanwil DJKN Jawa Timur melakukan proses perencanaan ini secara hati-hati. Berdasarkan informasi dari pejabat pengadaan, satuan kerja mencari informasi kepada beberapa pihak untuk mendapatkan langkah-langkah teknis yang harus ditempuh untuk pengadaan influencer. Informan mengatakan belum pernah melaksanakan pekerjaan ini sebelumnya sehingga memerlukan banyak informasi tentang pengadaan influencer.

Dalam rangka memenuhi kebutuhan jasa influencer pada satuan kerja, terdapat dua cara yakni swakelola dan melalui penyedia jasa. Pelaksanaan dengan swakelola yang dilaksanakan oleh instansi yang bersangkutan dengan menggunakan ASN milenial yang aktif di media sosial dan pelaksanaan penyedia dapat menggunakan penyedia jasa influencer. Mekanisme pengadaan influencer sendiri berpedoman pada aturan pengadaan barang dan jasa, yaitu termasuk pada pengadaan barang yang dikecualikan.

Satuan kerja Kanwil DJKN Jawa Timur menetapkan bahwa pekerjaan sosialisasi kebijakan mengenai lelang dilaksanakan melalui penyedia/pihak ketiga. Hal ini disebabkan pertimbangan penggunaan humas instansi belum bisa menjangkau secara luas. Informan berkomentar:

"Kami memutuskan untuk menggunakan influencer perorangan, karena nilainya kecil, Namun, bagaimana caranya itu yang kami belum tahu persis, sehigga harus banyak bertanya dan mencari informasi."

Dalam pelaksanaan kegiatan, kebutuhan jasa influencer melalui penyedia barang/jasa dilakukan melalui proses persiapan pengadaan jasa influencer oleh PPK, persiapan pemilihan dan pelaksanaan pemilihan jasa influencer oleh PP/Pokja Pemilihan dan pelaksanaan kontrak oleh PPK.

Informan menyebutkan

"Koordinasi dan komunikasi intensif dilakukan dengan PPK dan bagian keuangan untuk perhatian semua agar tidak bermasalah saat pelaksanaannya nanti." Hal ini sesuai dengan Grudinschi menyebutkan bahwa pengadaan layanan publik di domain sosial membutuhkan perhatian khusus karena merupakan bagian penting dari pengadaan layanan publik. Jika kebutuhan untuk sosialisasi kebijakan atau edukasi publik pada substansi tertentu, satuan kerja memerlukan pihak ketiga maka pengadaan influencer menjadi penting.

Kebutuhan jasa influencer merupakan sesuatu hal yang baru dalam pengadaan barang/jasa pemerintah. Berdasarkan pengamatan pada laman LPSE Kemendikbud dan Kemenparekraf, disebutkan bahwa pengadaan influencer masuk pada 
pengadaan jasa lainnya. Satker menggolongkan kebutuhan tersebut pada pengadaan yang bersifat umum.

Untuk kebutuhan pada nilai pengadaan sampai 200 juta rupiah, PPK menyusun Harga Perkiraan Sendiri (HPS) dengan menggunakan harga pasar, dan dalam pelaksanaan pemilihan penyedia, PP menggunakan metode pemilihan pengadaan langsung. Bentuk perikatan atau kontrak dilakukan dengan kuitansi untuk nilai pengadaan jasa influencer s.d 50 juta rupiah dan Surat Perintah Kerja untuk nilai pengadaan jasa influencer diatas 50 juta rupiah s.d. nilai 200 juta rupiah. Terdapat beberapa kendala dihadapi para pelaku pengadaan yaitu PPK dan PP/Pokja Pemilihan seperti penentuan HPS, cara pemilihan, metode evaluasi, dan penilaian kualifikasi sebagaimana dialami oleh respeonden satker Kanwil DJKN Jawa Timur. Informan menyebutkan bahwa terdapat kebutuhan jasa influencer yaitu pelaksanaan kegiatan sosialisasi kebijakan lelang unit kerja ke masyarakat. Maka satuan kerja mencari informasi pihak penyedia yaitu influencer yang memiliki jumlah followers banyak dan diyakini mampu menyebarluaskan informasi lelang.

Nilai pekerjaan di DIPA adalah dua puluh juta. Satuan kerja kemudian melakukan pemilihan influencer yang memiliki pengikut banyak dan terkenal di wilayah tersebut. Mekanisme pemilihan penyedia menggunakan pengadaan langsung. Influencer diminta untuk membuat video yang nantinya diunggah di kanal youtube miliknya. Tahap awal dilakukan pertemuan membahas substansi video. Tusi kantor tersebut dan serba serbi materi video dijelaskan kepada tim influencer. Harga dinegosiasikan dan mendapat harga akhir 18 juta rupiah untuk video selama 10 menit. Influencer ini memiliki 345 ribu subscriber. Output pekerjaan sudah diunggah di youtube dan mendapatkan view sebanyak 163.226 kali ditonton. Dalam realisasinya durasi video yang dibuat adalah 26.29 menit karena influencer memandang videonya turut membantu program pemerintah. Melalui influencer tersebut, kebijakan unit kerja dapat tersosialisasikan kepada publik yang lebih luas jangkauannya.

PP/Pokja pemilihan melaksanakan evaluasi terhadap penawaran yang disampaikan jasa influencer meliputi data :

1. Administrasi,

Dengan cara memeriksa kelengkapan dan pemenuhan dokumen penawaran terhadap surat penawaran

2. Teknis,

Dengan cara mengecek spesifikasi/KAK yang meliputi: apa spesifikasi teknis dari barang/bahan, metode pelaksanaan apa yang digunakan untuk melaksanakan pekerjaan, identifikasi jenis peralatan yang disediakan termasuk kapasitas, komposisi dan jumlah peralatan tersebut. Termasuk spesifikasi teknis adalah apakah ada layanan purna jual, berapa dan kompetensi tenaga teknis/terampil yang dimiliki, berapa lama jangka waktu pelaksanaan pekerjaan, apa identitas berupa merek, jenis, tipe barang/bahan. Selain itu pemenuhan spesifikasi teknis juga dengan memeriksa standar dari produk yang digunakan, apakah ada garansi atau asuransi atas barang/ bahan tersebut, apakah ada sertifikat/izin/hasil uji mutu/kelayakan teknis. Jika ada bagian pekerjaan yang 
akan disubkontrakkan, bagian/ pekerjaan apa saja. Persyaratan teknis ini disesuaikan dengan ruang lingkup pekerjaan.

3. Harga.

Pada metode pemilihan tender, penyedia jasa influencer harus memenuhi persyaratan kualifikasi penyedia yang meliputi aspek administrasi/legalitas (ijin usaha, TDP/NIB,NPWP); teknis (pengalaman); dan kemampuan keuangan. Untuk jasa influencer yang dilaksanakan oleh perorangan sebagaimana pada Kanwil DJKN Jawa Timur, maka aspek legalitas bagi jasa influencer perorangan tidak diperlukan ijin usaha, namun diperlukan identitas kewarganegaraan (KTP) dan NPWP dan sudah melaksanakan kewajiban perpajakan pada tahun terakhir. Aspek kemampuan keuangan pada jasa influencer dengan nilai paket sampai dengan 2,5 milyar rupiah, sehingga pengadaan jasa influencer pada satker Kanwil DJKN Jawa Timur tidak diperlukan kemampuan keuangan.

Pada metode pemilihan pengadaan langsung, tidak diperlukan adanya evaluasi kualifikasi jika berdasarkan pertimbangan dari pejabat pengadaan, penyedia/pelaku usaha jasa influencer memang telah memiliki kemahiran dan kesanggupan untuk melaksanakan pekerjaan tersebut. Dengan demikian pengadaan jasa influencer pada satker Kanwil DJKN Jawa Timur tidak diperlukan evaluasi kualifikasi.

Penulis berpendapat bahwa jasa influencer merupakan pengadaan yang bersifat khusus. Jasa influencer dapat berupa individu atau tim, yang merupakan suatu pekerjaan yang dilaksanakan secara profesional.
Dengan kata lain jasa influencer merupakan suatu profesi tertentu. Pengadaan jasa influencer dapat dikategorikan pengadaan yang dikecualikan pada sub kelompok jasa profesi tertentu dan sudah memiliki standar atas imbalan jasanya baik berupa honorarium/remunerasi, terdapat layanan keahlian, praktik marketing, dan kode etik yang sudah diputuskan oleh himpunan profesinya.

PPK menyusun rincian anggaran biaya berdasarkan remunerasi yang diterbitkan asosiasi jasa profesi dan memperhatikan pagu dalam DIPA, KAK, serta rancangan kontrak yang menjadi pedoman PP/Pokja pemilihan dalam melakukan persiapan dan pemilihan penyedia jasa influencer. PP/Pokja pemilihan dibantu tim teknis dalam menyusun kriteria teknis dan kewajaran harga pasar. Kriteria teknis dapat meliputi; kepribadian influencer, kemampuan kurasi, kredibilitas influencer, dan daya tarik influencer.

PP/Pokja pemilihan melakukan evaluasi dengan dibantu tim teknis dalam melaksanakan penilaian proposal berdasarkan basis kualitas yang diajukan influencer dan serta melakukan wawancara. Pada pemilihan dengan metode kompetisi, peserta terpilih yang ditetapkan adalah peserta yang mendapatkan nilai tertinggi. Kemduian PP/Pokja dapat membuat tindakan negosiasi harga. Pembayaran yang ditujukan kepada jasa influencer berdasarkan SPK atau surat perjanjian yang ditandatangani PPK dengan penyedia jasa influencer. Bentuk perikatan surat perjanjian digunakan untuk nilai pekerjaan jasa influencer diatas 200 juta rupiah, sedangkan SPK digunakan untuk nilai pekerjaan jasa influencer sampai dengan nilai 200 juta 
Tabel 5. Metode Pemilihan Jasa Influencer Melalui Pengadaan Umum

\begin{tabular}{|l|l|l|l|l|}
\hline No & Persiapan & Metode Pemilihan & Negosiasi Harga & Bentuk perikatan \\
\hline 1 & $\begin{array}{l}\text { Diperlukan HPS } \\
\text { berdasarkan } \\
\text { harga pasar }\end{array}$ & $\begin{array}{l}\text { Pengadaan langsung: } \\
\text { s.d 200 juta rupiah }\end{array}$ & $\begin{array}{l}\text { Dilakukan negosiasi } \\
\text { harga }\end{array}$ & $\begin{array}{l}\text { Bukti pembelian, } \\
\text { kuitansi, SPK }\end{array}$ \\
\hline 2 & $\begin{array}{l}\text { Tender: } \\
\text { Di atas 200 juta rupiah }\end{array}$ & $\begin{array}{l}\text { Negosiasi harga apabila } \\
\text { penyedia kurang dari 3 }\end{array}$ & SPK atau Surat perjanjian \\
\hline & $\begin{array}{l}\text { Jasa influencer mengajukan penawaran yang berisi data administrasi, data teknis, harga, dan kualifikasi } \\
\text { Penentuan evaluasi teknis berdasarkan spek teknis, metode pelaksanaan pekerjaan, tenaga } \\
\text { teknis/terampil, jangka waktu berdasarkan Perlem 9 tahun 2018 }\end{array}$ \\
\hline
\end{tabular}

Sumber: Penulis

Tabel 6. Metode Pemilihan Jasa Influencer Melalui Pengadaan Khusus

\begin{tabular}{|c|c|c|c|c|}
\hline No & Persiapan & Metode Pemilihan & Negosiasi Harga & Bentuk perikatan \\
\hline \multirow[t]{2}{*}{1} & \multirow{2}{*}{$\begin{array}{l}\text { Diperlukan RAB } \\
\text { mengacu pada } \\
\text { standar harga } \\
\text { asosiasi jasa } \\
\text { profesi influencer } \\
\text { dan Pagu dalam } \\
\text { DIPA }\end{array}$} & Kompetisi & $\begin{array}{l}\text { Dilakukan negosiasi } \\
\text { harga }\end{array}$ & SPK atau surat perjanjian \\
\hline & & $\begin{array}{l}\text { Non-kompetisi: } \\
\text { s.d } 200 \text { juta rupiah, } \\
\text { atau } \\
\text { hanya } 1 \text { pelaku usaha } \\
\text { yang mampu } \\
\text { menyediakan } \\
\text { portfolio/ hak ekslusif/ } \\
\text { reputasi yang dimiliki/ } \\
\text { disediakan jasa profesi } \\
\text { yang diperlukan }\end{array}$ & $\begin{array}{l}\text { Dilakukan negosiasi } \\
\text { harga }\end{array}$ & SPK atau surat perjanjian \\
\hline 2 & \multicolumn{4}{|c|}{$\begin{array}{l}\text { Jasa influencer mengajukan proposal berbasis kualitas. } \\
\text { Metode evaluasi: sistem nilai. } \\
\text { Penentuan kriteria teknis dan perkiraan biaya dibantu tim teknis }\end{array}$} \\
\hline
\end{tabular}

Sumber: Penulis

rupiah. Pengadaan yang dilakukan Kanwil DJKN Jawa Timur pada pelaksanaannya adalah menggunakan proses pengadaan dengan metode pemilihan penyedia bagi pengadaan yang bersifat khusus non-kompetisi.

Penentuan sifat pengadaan tersebut memengaruhi pelaku pengadaan dalam melalui pengadaan umum dengan tahapan proses pengadaannya sebagai diilustrasikan pada tabel 5.

Sedangkan pengadaan khusus untuk jasa influencer melalui tahapan proses pengadaannya sebagai ditampilkan pada tabel 6 .
Sering terjadi perubahan pada pengadaan barang dan jasa di Indonesia. Di Finlandia pelingkupan ulang proyek cenderung lebih menantang karena berhadapan dengan ketentuan hukum, karena penambahan kecil pada proyek dapat mengakibatkan keharusan untuk memulai pengadaan baru jika nilai yang terakumulasi naik di atas ambang batas nasional atau organisasi (Lee, 2020). Di Indonesia belum ada peraturan khusus yang mengatur pengadaan influencer sehingga ketika ada pengadaan influencer menggunakan peraturan mengenai pengadaan barang dan jasa pemerintah pada umumnya. 
Ketika satuan kerja melaksanakan pengadaan influencer, pengelola pengadaan memerlukan kompetensi tertentu. (Caniato, 2020) menyebutkan kompetensi pengadaan dan keterampilan yang paling penting saat ini adalah negosiasi, komunikasi dan manajemen hubungan, strategi dan analitik, dan persyaratan pengetahuan profesional. Hal ini dibenarkan oleh informan satker. Selain itu, keberlanjutan, digitalisasi, dan keterampilan interpersonal semakin dibutuhkan (Caniato, 2020). Perlu ada pembekalan tentang pemahaman pengadaan barang dan jasa untuk pengelola PBJ yang kompeten (Susanto, 2016), untuk meminimalisir lemahnya perlindungan hukum bagi pelaksana pengadaan barang/jasa (Manalu, 2017). Hal ini karena masih adanya pengadaan barang/jasa yang memenuhi unsur kolusif yang dilakukan secara berjenjang keatas yakni bersifat vertikal yaitu menyertakan panitia maupun kearah menyamping yang terjadi di kalangan para peserta tender (Maria \& Anggraini, 2013).

\section{KESIMPULAN DAN SARAN}

Paper ini menyoroti pengadaan influencer pada satuan kerja. Untuk meningkatkan kepercayaan masyarakat kepada pemerintah, maka penggunaan influencer menjadi hal yang wajar. Hal ini karena jangkauan influencer yang lebih luas dengan adanya jumlah pengikut yang banyak. Penggunaan influencer diharapkan dapat membantu edukasi dan penyampaian informasi ke publik lebih luas.

\footnotetext{
Identifikasi kebutuhan jasa influencer yang diperlukan harus mempertimbangkan besaran, beban tugas dan tanggung jawab organisasi,
}

serta jasa influencer yang dimiliki seperti influencer internal yang berasal dari ASN milenial pada satker. Pendataan internal satuan kerja atas ASN yang memiliki kompetensi di bidang digital perlu dilakukan. Hal ini untuk mempermudah proses identifikasi kebutuhan komunikasi publik ke depan. Kebutuhan jasa influencer perlu mempertimbangkan target yang diharapkan, fungsi dan manfaat yang dibutuhkan, serta waktu pelaksanaan.

Kebutuhan jasa influencer sebaiknya ditetapkan sebagai kebutuhan prioritas untuk memenuhi kebutuhan yang bersifat rutin yang harus diadakan setiap tahun. Kategori kebutuhan jasa influencer dapat mengacu kepada Klasifikasi Baku Komoditas Indonesia (KBKI), mengacu kepada KBKI yang diterbitkan BPS. Penulis berpendapat bahwa kebutuhan jasa influencer masuk pada seksi jasa perusahaan dan produksi atau seksi jasa keanggotaan organisasi.

Pengadaan jasa influencer pada satuan kerja pemerintah dapat dilaksanakan dengan melalui penyedia jasa influencer maupun swakelola. Pengadaan jasa influencer dengan cara swakelola dapat mengoptimalkan peran humas, sedangkan pengadaan jasa influencer melalui penyedia jasa influencer bukan merupakan bagian dari pengadaan barang/jasa umum, namun berada pada lingkup pengadaan bersifat khusus terhadap barang/jasa yang dikecualikan. Sehingga dalam pelaksanaannya mendapat pengecualian baik sebagian maupun seluruhnya dari ketentuan sebagaimana diatur dalam Perpres Pengadaan Barang dan Jasa. Dengan 
anggaran publikasi yang dimiliki satuan kerja pemerintah, KPA dapat menentukan pemakaian jasa influencer untuk kegiatan publikasi. Penentuan influencer yang akan digunakan adalah dengan memperhatikan pemenuhan kriteria teknis oleh influencer terhadap kriteria teknis yang telah ditetapkan sebelumnya oleh PP/Pokja Pemilihan dibantu tim teknis. Metode pemilihan jasa influencer dapat menggunakan metode pemilihan kompetisi maupun non-kompetisi.

Dengan banyaknya peristiwa hukum berupa pengadaan influencer ini pada dunia swasta, maka pada saat pemerintah melaksanakan pengadaaan influencer ini dapat mengacu pada apa yang terjadi di swasta, dengan kondisi sebagai praktik bisnis yang sudah mapan. Oleh karena itu penulis berpendapat bahwa pengadaan influencer masuk pada kategori metode Pemilihan Pengadaan Bersifat Khusus terhadap Barang/Jasa Lainnya/ Jasa Konsultansi yang dikecualikan yaitu pada PBJ yang pelaksanaannya berada pada praktik bisnis yang mapan. Hal ini sejalan dengan pendapat Sutedi (2010) bahwa untuk melaksanakan reformasi di bidang pengadaan, ada tiga hal yang perlu diperhatikan, yaitu pembenahan regulasi, pengembangan SDM, dan pembenahan kelembagaan.

\section{IMPLIKASI DAN}

\section{KETERBATASAN}

Paper ini berimplikasi pada pembuatan aturan khusus mengenai pengadaan influencer, terutama tentang mekanisme pemilihan penyedia, tata cara pemilihan, penatausahaan dan pembayarannya. Penelitian ini dilakukan pada ruang lingkup terbatas pada kajian literatur sehingga memungkinkan ada data lain yang belum dimasukkan. Pendekatan yuridis empiris digunakan untuk mendapat pemahaman yang utuh terhadaap tema penelitian. Penelitian ini belum menyentuh pada pendekatan lain yang bisa jadi lebih tepat digunakan. Perlunya dilakukan analisis berdasarkan metode yuridis normatif untuk memperkuat sisi hukum pelaksanaan pemilihan penyedia jasa influencer.

\section{REFERENCES}

\section{Anjani, S. \& I. (2020). Peranan Influencer Dalam Mengkomunikasikan Pesan Di Media Sosial Instagram [the Role of Social Media Influencers in Communicating Messages Using Instagram]. Polyglot: Jurnal Ilmiah, 16(2), 203. https://doi.org/10.19166/pji.v16i2 .1929}

Arora, N., \& Talwar, S. J. (2020). Modelling efficiency in budget allocations for Indian states using window based non-radial nonconcave metafrontier data envelopment analysis. SocioEconomic Planning Sciences, 70 (January), 100735. https://doi.org/10.1016/j.seps.20 19.100735

Arsyad, M., Suriadi, L. O., \& Anam, S. (2016). Analisis Pengadaan Barang dan Jasa secara Elektronik (E-procurement) Pada LPSE Kota Kendari. Jurnal Ekonomi (JE), 1(April), 1-11.

Baldus, B. J. \& Hatton, L. B. (2020). U.S. chief procurement officers' 
perspectives on public

procurement. Journal of Purchasing and Supply Management, 26(1), 100538. https://doi.org/10.1016/j.pursup. 2019.05.003

Betham, A. A. B., Hipan, N. \& Fality, F. (2019). Analisis Yuridis Prosedur Pengadaan Barang/Jasa Pemerintah Serta Perlindungan Hukum Terhadap Pelaku Pengadaan Barang/Jasa. Jurnal Yustisiabel, 3(2), 191. https://doi.org/10.32529/yustisia bel.v3i2.398

Caloghirou, Y., Protogerou, A. \& Panagiotopoulos, P. (2016). Public procurement for innovation: A novel eGovernment services scheme in Greek local authorities. Technological Forecasting and Social Change, 103, 1-10. https://doi.org/10.1016/j.techfore .2015.10.016

Caniato, F., Harland, C., Johnsen, T., Moretto, A., \& Ronchi, S. (2020). The Art and Science of Procurement: Revisiting Leonardo da Vinci: Editorial of the 2019 IPSERA Conference Special Issue. Journal of Purchasing and Supply Management, 26(4). https://doi.org/10.1016/j.pursup. 2020.100650

Denzin, N. K. \& Lincoln, Y. S. (2009). Hand Book of Qualitative Research. Yogyakarta: Pustaka Pelajar.

Direktorat Jenderal Aplikasi Informatika. (n.d.). Menkominfo: Penggunaan Influencer oleh Pemerintah Tidak Salah. Retrieved from

https://aptika.kominfo.go.id/2020 /09/menkominfo-penggunaan- influencer-oleh-pemerintahtidak-salah/

Grudinschi, D., Sintonen, S. \& Hallikas, J. (2014). Relationship risk perception and determinants of the collaboration fluency of buyer-supplier relationships in public service procurement. Journal of Purchasing and Supply Management, 20(2), 82-91. https://doi.org/10.1016/j.pursup. 2014.03.004

Haryati, D., Anditya, A., \& Wibowo, R. A. (2011). Pelaksanaan Pengadaan Barang/Jasa Secara Elektronik (EProcurement) Pada Pemerintah Kota Yogyakarta. Mimbar HukumFakultas Hukum Universitas Gadjah Mada, 23(2), 328-342

Hutagalung, B., Wardani, D. K., Vidya, M. (2015). Negosiasi dalam Pengadaan Barang dan Jasa Oleh Pemerintah Sebagai Upaya Mencapai Kesepakatan. Privat Law, 7 Januari-Juni 2015.

Indonesian Corruption Watch. (2020). Aktivitas Digital Pemerintah: Berapa Milyar Anggaran Influencer. Retrieved from https://antikorupsi.org/sites/defa ult/files/dokumen/Digital-

Influencer.pdf

Instruksi Presiden Nomor 9 tahun 2015 Pengelolaan Komunikasi Publik. Jakarta.

Ishaq. (2017). Metode Penelitian Hukum dan Penulisan Skripsi, Tesis, Serta Disertasi. Bandung: Alfabeta.

Kantor Staf Presiden. (2020). Penanganan covid-19 Protokol Komunikasi Publik. Retrieved from http://ksp.go.id/wpcontent/uploads/2020/03/Protok ol-Komunikasi-COVID-19.pdf 
Kementerian Keuangan. (2018). Keterangan Pers Peran Penting Pengadaan Barang/Jasa Sebagai Bagian Dari Pengelolaan Keuangan Negara. Retrieved from https://www.kemenkeu.go.id/pub likasi/siaran-pers/keteranganpers-peran-penting-pengadaanbarangjasa-sebagai-bagian-daripengelolaan-keuangan-negara

Kementerian Komunikasi dan Informatika. (2018).

Memaksimalkan Penggunaan Media Sosial Dalam Lembaga Pemerintah. Jakarta.

Kementerian Pariwisata dan Ekonomi Kreatif. (2020). Paket Pekerjaan Pengadaan Influencer Kemenparekraf. Retrieved from https://lpse.kemenparekraf.go.id/ eproc4/lelang

Lee, S. (2020). Contexts of briefing for service design procurements in the Finnish public sector. Design Studies, 69, 100945 . https://doi.org/10.1016/j.destud. 2020.05.002.

Manalu, J. B. (2017). Penyelenggara Pengadaan Barang/Jasa Pemerintah. Jurnal Hukum Samudra Keadilan 12, 296-310.

Marbun, R. (2010). Tanya Jawab Seputar Pengadaan Barang/Jasa Pemerintahan. Jakarta: Visi Media.

Maria, A., \& Anggraini, T. (2013). Sinergi BUMN Dalam Pengadaan Barang dan/atau Jasa Dalam Perspektif Persaingan Usaha. Mimbar Hukum - Fakultas Hukum Universitas Gadjah Mada, 25(3), 446-460.

https://doi.org/10.22146/jmh.160 72

Mulyono, P. E. (2017). Analisis Pelaksanaan

Pengadaan
Barang/Jasa secara Elektronik pada Pemerintah Kabupaten Gresik. Airlangga Development Journal 1, 32-42.

Nayabarani, S. D. (2018). Membangun Transparansi Pengadaan Barang Dan Jasa Melalui Peningkatan Peran Ict Dalam Mereduksi Korupsi. Jurnal Hukum \& Pembangunan, 47(4), 477. https://doi.org/10.21143/.vol47.n 04.1586

Pemerintah Indonesia bayar influencer Rp90 miliar untuk sosialiasi kebijakan, "buang duit yang efektif?". (2020, August 20). BBC News Indonesia. Retrieved from https://www.bbc.com/indonesia/i ndonesia-53846128

Peraturan LKPP Nomor 12 tahun 2018 Pedoman Pengadaan Barang/Jasa yang Dikecualikan pada Pengadaan Barang/Jasa Pemerintah. Jakarta.

Peraturan LKPP Nomor 9 tahun 2018 Pedoman Pelaksanaan Pengadaan Barang/Jasa Melalui Penyedia. Jakarta.

Peraturan Menteri Keuangan Republik Indonesia Nomor 196/PMK.02/2015 Petunjuk Penyusunan dan Penelaahaan RKA-K/L dan Pengesahan DIPA. Jakarta.

Peraturan Presiden Nomor 16 Tahun 2018 Pengadaan Barang/Jasa Pemerintah. Jakarta.

Strauss, A. \& Corbin, J. (2017). DasarDasar Penelitian Kualitatif. Yogyakarta: Pustaka Pelajar.

Susanto, Y. (2016). Kompetensi, Kompensasi Dan Sanksi Hukum Pengaruhnya Terhadap Perilaku Aparatur Dalam Pengadaan 
Barang/Jasa Di Kota Palembang. Journal Ecoment Global, 1(1).

Sutedi, A. (2010). Aspek Hukum Pengadaan Barang dan Jasa dan Berbagai Permasalahannya. Jakarta: Sinar Grafika.

Uenk, N. \& Telgen, J. (2019). Managing challenges in social care service triads - Exploring public procurement practices of Dutch municipalities. Journal of Purchasing and Supply Management, 25(1), 5-17. https://doi.org/10.1016/j.pursup. 2018.08.001

Wahyuni, H. \& Ambardi, K. (2020). Problem Infodemic dalam merespon Pandemi Covid-19. Policy Brief, 2201, 14. https://fisipol.ugm.ac.id/wpcontent/uploads/sites/1056/2020 /04/Policy-Brief-ProblemInfodemic-dalam-MeresponPandemi-COVID-19.pdf

Wynstra, F., Rooks, G. \& Snijders, C. (2018). How is service procurement different from goods procurement? Exploring ex ante costs and ex post problems in IT procurement. Journal of Purchasing and Supply Management, 24(2), 83-94. https://doi.org/10.1016/j.pursup. 2017.12.001

Yukins, C. \& Schooner, S. (2007). Incrementalism: Eroding the Impediments to a Global Public Procurement Market. Journal of International Law, 38, 529-576.

Yulianto, A. B. (2017). Upaya Keberatan Dalam Pengadaan Barang/Jasa Pemerintah Dikaitkan Dengan Prinsip Dalam Government Procurement Agreement. Veritas et Justitia, 3(1), 195. https://doi.org/10.25123/vej.2530 